\title{
A FORMULA AND NOMOGRAM FOR THE ESTIMATION OF THE OSMOTIC PRESSURE OF COLLOIDS FROM THE ALBUMIN AND TOTAL PROTEIN CONCENTRATIONS OF HUMAN BLOOD SERA
}

\author{
By HERBERT S. WELLS, JOHN B. YOUMANS, AND DAVID G. MILLER, JR.
}

(From the Departments of Physiology and Medicine, Vanderbilt University Medical School, Nashoille)

(Received for publication July 31, 1933)

In connection with investigations to be reported subsequently the osmotic pressure of colloids and the albumin and total protein concentrations of 128 samples of human blood serum were determined. From these data, which cover a wide range of values, an empirical formula has been evolved which, it is believed, will enable the osmotic pressure to be more accurately estimated from the protein analyses of human sera than is the case with formulae now employed for this purpose $(1,2)$. A nomogram has been constructed to facilitate such computations. The simple, definitely linear relation found to exist between the albumin concentration and the specific osmotic pressure would indicate that the albumin : globulin ratio is not as reliable an index of the osmotic properties of serum as is at present of ten assumed.

It may justly be contended-at least on theoretical grounds-that the accuracy of most of the colloid osmotic pressure measurements previously carried out on human blood sera is open to serious question, either for the reason that the authors have failed to recognize the fundamental criteria of equilibrium upon which any good physical chemist would insist (3) or because of the failure to describe the methods employed in sufficient detail to enable one to judge as to whether such criteria have actually been fulfilled.

In a recent communication (4) it was emphasized that, for the accurate determination of the osmotic pressure of colloids, it is essential to observe certain rigid criteria of an osmotic equilibrium. Procedures were described by which these criteria of accuracy might be fulfilled, and a detailed description of the apparatus and methods has recently been published (5). By a strict adherence to such standards it has been possible, during the present investigation, to obtain from duplicate determinations on each serum pressure values which, in 95 per cent of the cases, do not differ by more than $12 \mathrm{~mm}$. of water. No pressure reading has been considered to be accurate unless it has been possible to maintain the volume of the serum at a constant value, at this pressure 
and at constant temperature, for a period of at least two hours-a period of observation sufficient, according to our tests, to insure the attainment of a definite equilibrium when the membranes are of the standard selected permeability. Consequently, it is believed that our figures actually refer to equilibrium pressures. The fact that the standard per cent deviation of the calculated from the observed values of the osmotic pressure is only \pm 5 per cent leads us to believe, furthermore, that for routine clinical purposes, the method of calculation, which avoids the many difficulties inherent in the usual methods of direct determination, will provide a sufficiently reliable index of the water-retaining power of the serum. Such a conclusion is, however, to be considered as subject to the same qualifications as apply to all cases of indirect measurements, as for example, the estimation of the basal metabolic rate from the oxygen consumption. The possibilities of error in the use of the calculated figures will be discussed in later paragraphs.

\section{METHODS}

Protein analyses were carried out in duplicate by the macro-Kjeldahl method on samples drawn under oil without stasis. Globulin was separated by precipitation at $38^{\circ} \mathrm{C}$. with 22.5 per cent sodium sulphate according to the method of Howe (6). Nonprotein nitrogen was estimated by the micro-Kjeldahl-Nesslerization method, on oxalated plasma. The usual factor, 6.25 , was used to convert protein nitrogen values to protein concentrations.

The osmotic pressure determinations were carried out in a constant temperature room at $20^{\circ}$ to $22^{\circ} \mathrm{C}$. Duplicate determinations were done in all but four instances. The collodion membranes used were standardized to a specific permeability (4) range of $20 \times 10^{-8}$ to $40 \times 10^{-8}$. Equilibrium was usually attained in 1 to 3 hours, but a somewhat longer time was occasionally required. The details of the method and the criteria of osmotic equilibrium have been described elsewhere $(4,5)$. Occasional lapses of the vigilant attention to detail which is necessary for success in carrying out such determinations invariably led to gross errors which necessitated discarding the results. On the other hand, all data have been included for which definite evidence of gross errors of technic was lacking, regardless of the degree of variation between the duplicate determinations.

\section{DATA}

The blood samples were taken from 53 individuals, from 1 to 10 determinations being carried out on each person, often over periods of several months. Of these 53 persons 14 were laboratory workers, students, and other volunteers, all apparently in good health; 20 presented, at one time or another, and to various degrees, evidences of nutritional edema; 12 had heart disease; and 1 each suffered from the following 
pathological conditions: multiple xanthomatosis, chronic diarrhea, aplastic anemia, pellagra with chronic colitis, Banti's disease, nephrosis, syphilitic cirrhosis of the liver.

The data are presented in Table I, arranged in order of increasing albumin concentrations. The 10 lowest albumin, total protein and osmotic pressure figures were obtained from a single individual, over a period of 5 months during the gradual decline associated with an advanced nephrosis. The 13 highest values were obtained from blood which had been concentrated by causing the subjects to stand in the erect posture for one hour or longer, in connection with experiments which are to be described elsewhere. The extreme range of the values encountered may be indicated by the following figures: albumin, per cent, 0.89 to 6.62 ; globulin, 1.66 to 6.48 ; total protein, 2.99 to 9.64 ; albumin: globulin ratio, 0.42 to 2.80 ; osmotic pressure of colloids, 76 to $583 \mathrm{~mm}$. water; and specific osmotic pressure, 25.4 to $59.2 \mathrm{~mm}$. water. The figures for the albumin concentrations probably furnish the best index as to the distribution of the values. There were 10 albumin values below $2.5 ; 13$ between 2.5 and $3.5 ; 50$ between 3.51 and $4.5 ; 48$ between 4.51 and 5.5 ; and 7 above 5.5 .

\section{ANALYSIS OF THE DATA}

The specific osmotic pressure, $\mathrm{S}$, was calculated for each case by dividing the value of the total osmotic pressure, $\mathrm{P}$, measured in $\mathrm{mm}$. of water, by the concentration of total proteins, $\mathrm{C}$, measured in grams per $100 \mathrm{cc}$. Values for the specific pressures were plotted on a threedimensional graph against the corresponding values of the albumin and of the globulin concentrations. This was done by driving wires, sharpened at one end, into the drawing board on which the axes of albumin and globulin concentrations (A and G) were laid off on crosssection paper. Each value of $\mathrm{S}$ was thus represented by the height of a wire and the point through which the wire was driven represented the corresponding $A$ and $G$ values. The surface produced by the tips of the wires was seen to be fairly regular, but contrary to our earlier expectations it did not show any obvious relation between the specific osmotic pressure and the globulin concentration or $A / G$ ratio. The formula of Govaerts (1) implies the assumption that the specific pressure is determined primarily by the $A / G$ ratio. According to his concept the value of $S$ will fall with increasing values of $G$ for sera having a constant value of A. Govaerts also assumes that the total protein concentration, C, is without effect on the value of $S$ in the case of sera which have the same $A / G$ ratio. In our series there is an obvious and regular relation between $\mathrm{C}$ and $\mathrm{S}$ and it was apparent, from inspection of the wire model, that the increasing values of $S$, as $C$ increased, were due entirely to the increase in $A$. The relation between the specific pressure and the albumin was 
TABLE I

Data arranged in ascending order of albumin concentrations

\begin{tabular}{|c|c|c|c|c|c|c|c|c|c|}
\hline $\begin{array}{c}\text { Case } \\
\text { number }\end{array}$ & Albumin & $\begin{array}{l}\text { Specific } \\
\text { pressure, } \\
\text { observed }\end{array}$ & \begin{tabular}{|c} 
Specific \\
pressure, \\
calcu- \\
lated
\end{tabular} & $\begin{array}{c}\text { Total } \\
\text { protein }\end{array}$ & $\begin{array}{l}\text { Osmotic } \\
\text { pressure, } \\
\text { observed }\end{array}$ & $\begin{array}{c}\text { Osmotic } \\
\text { pressure, } \\
\text { calcu- } \\
\text { lated }\end{array}$ & $\begin{array}{l}\text { Varia- } \\
\text { tion of } \\
\text { calcu- } \\
\text { lated } \\
\text { from } \\
\text { observed } \\
\text { pressure }\end{array}$ & $\begin{array}{c}\text { Maxi- } \\
\text { mum ex- } \\
\text { perimen- } \\
\text { tal error }\end{array}$ & $\begin{array}{l}\text { Unex- } \\
\text { plained } \\
\text { vari- } \\
\text { ations }\end{array}$ \\
\hline & $\begin{array}{c}\text { grams } \\
\text { per } \\
100 \text { cc. }\end{array}$ & ${ }_{H_{2}}^{m m} \mathrm{O}$ & $\underset{\mathrm{H}_{2} \mathrm{O}}{\mathrm{mm}}$ & $\begin{array}{c}\text { grams } \\
\text { per } \\
100 \text { cc. }\end{array}$ & $\underset{\mathrm{H}_{2} \mathrm{~mm}}{\mathrm{O}}$ & $\underset{\mathrm{H}_{2} \mathrm{~m} . \mathrm{O}}{2}$ & $\underset{\mathrm{H}_{2} \mathrm{O} \mathrm{O}}{\mathrm{m}}$ & $\underset{H_{2} \mathrm{~m}}{m}$ & $\underset{\mathrm{H}_{2} \mathrm{~m}}{\mathrm{O}}$. \\
\hline 37 & 0.89 & 25.4 & 26.7 & 2.99 & 76 & 80 & +4 & \pm 21 & \\
\hline 37 & 1.25 & 30.9 & 28.8 & 3.10 & 96 & 89 & -7 & \pm 22 & \\
\hline 37 & 1.46 & 29.3 & 30.0 & 3.35 & 98 & 101 & +3 & \pm 22 & \\
\hline 37 & 1.75 & 30.1 & 31.7 & 3.56 & 107 & 113 & +6 & \pm 23 & \\
\hline 37 & 1.93 & 31.2 & 32.8 & 3.59 & 112 & 118 & +6 & \pm 23 & \\
\hline 37 & 1.93 & 30.4 & 32.8 & 3.71 & 113 & 122 & +9 & \pm 23 & \\
\hline 37 & 1.94 & 31.3 & 32.8 & 3.89 & 122 & 128 & +6 & \pm 23 & \\
\hline 37 & 2.28 & 38.6 & 34.9 & 4.09 & 158 & 143 & -15 & \pm 24 & \\
\hline 37 & 2.41 & 34.6 & 35.6 & 4.16 & 144 & 148 & +4 & \pm 24 & \\
\hline 37 & 2.44 & 32.2 & 35.8 & 4.28 & 138 & 153 & +15 & \pm 24 & \\
\hline 35 & 2.57 & 34.1 & 36.6 & 4.36 & 149 & 159 & +10 & \pm 25 & \\
\hline 26 & 2.67 & 39.5 & 37.2 & 5.92 & 234 & 220 & -14 & \pm 27 & \\
\hline 20 & 2.80 & 43.6 & 37.9 & 5.92 & 258 & 224 & -34 & \pm 27 & -7 \\
\hline 36 & 2.87 & 41.5 & 38.3 & 9.35 & 388 & 358 & -30 & \pm 31 & \\
\hline 49 & 3.11 & 40.9 & 39.7 & 4.88 & 199 & 194 & -5 & \pm 26 & \\
\hline 47 & 3.19 & 39.7 & 40.2 & 5.74 & 228 & 231 & +3 & \pm 27 & \\
\hline 47 & 3.19 & 41.0 & 40.2 & 5.68 & 233 & 228 & -5 & \pm 27 & \\
\hline 47 & 3.20 & 39.0 & 40.3 & 5.84 & 228 & 235 & +7 & \pm 27 & \\
\hline 49 & 3.30 & 43.4 & 40.9 & 4.98 & 216 & 204 & -12 & \pm 26 & \\
\hline 49 & 3.30 & 39.6 & 40.9 & 5.10 & 202 & 208 & +6 & \pm 26 & \\
\hline 47 & 3.34 & 40.8 & 41.1 & 5.64 & 230 & 232 & +2 & \pm 27 & \\
\hline 49 & 3.46 & 39.8 & 41.8 & 5.18 & 206 & 217 & +11 & \pm 27 & \\
\hline 32 & 3.49 & 42.7 & 42.0 & 7.61 & 325 & 320 & -5 & \pm 30 & \\
\hline 49 & 3.52 & 47.6 & 42.2 & 5.15 & 245 & 217 & -28 & \pm 27 & -1 \\
\hline 31 & 3.60 & 43.4 & 42.6 & 6.38 & 277 & 272 & -5 & \pm 28 & \\
\hline 49 & 3.61 & 45.7 & 42.7 & 6.10 & 279 & 260 & -19 & \pm 28 & \\
\hline 31 & 3.62 & 43.7 & 42.8 & 6.58 & 288 & 281 & -7 & \pm 28 & \\
\hline 47 & 3.67 & 36.3 & 43.1 & 6.71 & 244 & 289 & +45 & \pm 29 & +16 \\
\hline 31 & 3.67 & 37.5 & 43.1 & 6.33 & 237 & 273 & +36 & \pm 28 & +8 \\
\hline 23 & 3.70 & 41.3 & 43.2 & 6.27 & 259 & 271 & +12 & \pm 28 & \\
\hline 49 & 3.70 & 42.1 & 43.2 & 5.25 & 221 & 227 & +6 & \pm 27 & \\
\hline 38 & 3.73 & 44.6 & 43.4 & 7.15 & 319 & 310 & -9 & \pm 29 & \\
\hline 32 & 3.73 & 46.3 & 43.4 & 8.09 & 375 & 351 & -24 & \pm 31 & \\
\hline 32 & 3.80 & 42.6 & 43.8 & 7.44 & 317 & 326 & +9 & \pm 30 & \\
\hline 52 & 3.82 & 43.0 & 43.9 & 6.45 & 277 & 283 & +6 & \pm 29 & \\
\hline 23 & 3.83 & 46.4 & 44.0 & 6.66 & 309 & 293 & -16 & \pm 29 & \\
\hline 33 & 3.94 & 43.3 & 44.6 & 6.50 & 281 & 290 & +9 & \pm 29 & \\
\hline 42 & 3.98 & 45.9 & 44.9 & 6.99 & 321 & 314 & -7 & \pm 29 & \\
\hline 48 & 4.01 & 44.9 & 45.1 & 6.82 & 306 & 307 & +1 & \pm 29 & \\
\hline 22 & 4.03 & 45.0 & 45.2 & 6.71 & 302 & 303 & +1 & \pm 29 & \\
\hline 38 & 4.04 & 43.8 & 45.2 & 6.98 & 306 & 316 & +10 & \pm 30 & \\
\hline 23 & 4.04 & 45.7 & 45.2 & 7.12 & 325 & 322 & -3 & \pm 30 & \\
\hline 10 & 4.05 & 47.6 & 45.3 & 6.49 & 309 & 294 & -15 & \pm 29 & \\
\hline 10 & 4.10 & 49.1 & 45.6 & 6.38 & 313 & 291 & -22 & \pm 29 & \\
\hline
\end{tabular}


H. S. WELLS, J. B. YOUMANS AND D. G. Miller, JR.

TABLE I (continued)

\begin{tabular}{|c|c|c|c|c|c|c|c|c|c|}
\hline $\begin{array}{c}\text { Case } \\
\text { number }\end{array}$ & Albumin & \begin{tabular}{|}
$\begin{array}{c}\text { Specific } \\
\text { pressure, } \\
\text { observed }\end{array}$ \\
int
\end{tabular} & \begin{tabular}{|c} 
Specific \\
pressure, \\
calcu- \\
lated
\end{tabular} & $\begin{array}{c}\text { Total } \\
\text { protein }\end{array}$ & $\begin{array}{l}\text { Osmotic } \\
\text { pressure, } \\
\text { observed }\end{array}$ & $\begin{array}{l}\text { Osmotic } \\
\text { pressure, } \\
\text { calcu- } \\
\text { lated }\end{array}$ & $\begin{array}{c}\text { Varia- } \\
\text { tion of } \\
\text { calcu- } \\
\text { lated } \\
\text { from } \\
\text { observed } \\
\text { pressure }\end{array}$ & $\begin{array}{c}\text { Maxi- } \\
\text { mum ex- } \\
\text { perimen- } \\
\text { tal error }\end{array}$ & $\begin{array}{c}\text { Unex- } \\
\text { plained } \\
\text { vari- } \\
\text { ations }\end{array}$ \\
\hline & $\begin{array}{c}\text { grams } \\
\text { per } \\
100 \text { cc. }\end{array}$ & $\underset{H_{2} \mathrm{O}}{m_{2}}$ & $\underset{H_{3} \mathrm{O}}{\boldsymbol{m}_{2}}$ & $\begin{array}{c}\text { grams } \\
\text { per } \\
100 \text { cc. }\end{array}$ & $\underset{H_{2} \mathrm{O}}{m_{2}}$ & ${ }_{H_{3} \mathrm{O}}^{m m}$ & $\underset{H_{3} \mathrm{O}}{m_{0}}$ & $\underset{H_{2} \mathrm{O}}{m m}$ & $\underset{\mathrm{H}_{3} \mathrm{~m}}{\mathrm{O}}$ \\
\hline 7 & 4.11 & 44.2 & 45.6 & 7.95 & 352 & 363 & +11 & \pm 31 & \\
\hline 12 & 4.13 & 47.1 & 45.8 & 6.33 & 298 & 290 & -8 & \pm 29 & \\
\hline 16 & 4.14 & 44.1 & 45.8 & 7.01 & 309 & 321 & +12 & \pm 30 & \\
\hline 33 & 4.16 & 44.3 & 45.9 & 6.77 & 300 & 311 & +11 & \pm 29 & \\
\hline 23 & 4.19 & 44.2 & 46.1 & 6.92 & 306 & 319 & +13 & \pm 30 & \\
\hline 4 & 4.22 & 46.4 & 46.3 & 7.06 & 328 & 327 & -1 & \pm 30 & \\
\hline 31 & 4.22 & 49.2 & 46.3 & 7.54 & 371 & 349 & -22 & \pm 30 & \\
\hline 17 & 4.23 & 45.8 & 46.4 & 7.08 & 324 & 328 & +4 & \pm 30 & \\
\hline 17 & 4.25 & 49.4 & 46.5 & 6.82 & 337 & 317 & -20 & \pm 30 & \\
\hline 17 & 4.27 & 47.7 & 46.6 & 6.67 & 318 & 311 & -7 & \pm 29 & \\
\hline 28 & 4.27 & 48.6 & 46.6 & 5.99 & 291 & 279 & -12 & \pm 29 & \\
\hline 24 & 4.30 & 49.1 & 46.8 & 6.49 & 319 & 304 & -15 & \pm 29 & \\
\hline 3 & 4.33 & 47.2 & 46.9 & 6.65 & 314 & 312 & -2 & \pm 29 & \\
\hline 50 & 4.33 & 45.5 & 46.9 & 8.18 & 372 & 384 & +12 & \pm 31 & \\
\hline 3 & 4.36 & 48.7 & 47.1 & 6.47 & 315 & 305 & -10 & \pm 29 & \\
\hline 29 & 4.37 & 48.0 & 47.2 & 7.06 & 339 & 333 & -6 & \pm 30 & \\
\hline 6 & 4.38 & 45.4 & 47.2 & 7.11 & 323 & 336 & +13 & \pm 30 & \\
\hline 25 & 4.39 & 45.0 & 47.3 & 7.25 & 326 & 343 & +17 & \pm 30 & \\
\hline 4 & 4.39 & 48.0 & 47.3 & 7.11 & 341 & 336 & -5 & \pm 30 & \\
\hline 17 & 4.40 & 47.7 & 47.4 & 6.64 & 316 & 314 & -2 & \pm 30 & \\
\hline 9 & 4.41 & 47.3 & 47.4 & 7.06 & 334 & 335 & +1 & \pm 30 & \\
\hline 16 & 4.42 & 46.4 & 47.5 & 6.70 & 311 & 318 & +7 & \pm 30 & \\
\hline 8 & 4.42 & 47.2 & 47.5 & 6.80 & 321 & 323 & +2 & \pm 30 & \\
\hline 2 & 4.43 & 42.8 & 47.5 & 6.48 & 277 & 308 & +31 & \pm 29 & +2 \\
\hline 30 & 4.44 & 47.0 & 47.6 & 7.10 & 334 & 338 & +4 & \pm 29 & \\
\hline 15 & 4.46 & 49.8 & 47.7 & 6.26 & 312 & 299 & -13 & \pm 29 & \\
\hline 44 & 4.46 & 48.4 & 47.7 & 6.92 & 335 & 330 & -5 & \pm 30 & \\
\hline 43 & 4.48 & 51.2 & 47.8 & 6.64 & 340 & 318 & -22 & \pm 30 & \\
\hline 9 & 4.49 & 48.9 & 47.9 & 6.99 & 342 & 335 & -7 & \pm 30 & \\
\hline 29 & 4.50 & 45.7 & 48.0 & 7.10 & 325 & 340 & +15 & \pm 30 & \\
\hline 8 & 4.50 & 51.0 & 48.0 & 7.12 & 363 & 341 & -22 & \pm 30 & \\
\hline 24 & 4.52 & 46.3 & 48.1 & 6.78 & 314 & 326 & +12 & \pm 30 & \\
\hline 29 & 4.52 & 44.9 & 48.1 & 7.07 & 317 & 340 & +23 & \pm 30 & \\
\hline 5 & 4.52 & 49.8 & 48.1 & 6.33 & 315 & 304 & -11 & \pm 29 & \\
\hline 17 & 4.53 & 47.2 & 48.1 & 7.44 & 351 & 358 & +7 & \pm 31 & \\
\hline 3 & 4.54 & 48.3 & 48.2 & 6.63 & 320 & 319 & -1 & \pm 30 & \\
\hline 51 & 4.55 & 52.8 & 48.2 & 6.35 & 335 & 306 & -29 & \pm 29 & \\
\hline 21 & 4.57 & 49.2 & 48.4 & 6.69 & 329 & 324 & -5 & \pm 30 & \\
\hline 8 & 4.59 & 46.8 & 48.5 & 6.72 & 314 & 326 & +12 & \pm 30 & \\
\hline 30 & 4.59 & 49.6 & 48.5 & 6.86 & 340 & 333 & -7 & \pm 30 & \\
\hline 30 & 4.60 & 48.8 & 48.5 & 7.27 & 355 & 353 & -2 & \pm 31 & \\
\hline 30 & 4.62 & 44.8 & 48.7 & 7.12 & 319 & 346 & +27 & \pm 30 & \\
\hline 39 & 4.62 & 48.6 & 48.7 & 6.85 & 333 & 333 & 0 & \pm 30 & \\
\hline 8 & 4.62 & 48.2 & 48.7 & 6.91 & 333 & 336 & +3 & \pm 30 & \\
\hline 15 & 4.63 & 51.2 & 48.7 & 6.53 & 334 & 318 & -16 & \pm 30 & \\
\hline 41 & 4.64 & 51.5 & 48.8 & 6.87 & 354 & 335 & -19 & \pm 30 & \\
\hline
\end{tabular}


TABLE I (continued)

\begin{tabular}{|c|c|c|c|c|c|c|c|c|c|}
\hline $\begin{array}{c}\text { Case } \\
\text { number }\end{array}$ & Albumin & $\begin{array}{c}\text { Specific } \\
\text { pressure, } \\
\text { observed }\end{array}$ & $\begin{array}{c}\text { Specific } \\
\text { pressure, } \\
\text { calcu- } \\
\text { lated }\end{array}$ & $\begin{array}{c}\text { Total } \\
\text { protein }\end{array}$ & $\begin{array}{l}\text { Osmotic } \\
\text { pressure, } \\
\text { observed }\end{array}$ & $\begin{array}{c}\text { Osmotic } \\
\text { pressure, } \\
\text { calcu- } \\
\text { lated }\end{array}$ & $\begin{array}{c}\text { Varia- } \\
\text { tion of } \\
\text { calcu- } \\
\text { lated } \\
\text { from } \\
\text { observed } \\
\text { pressure }\end{array}$ & $\begin{array}{l}\text { Maxi- } \\
\text { mum ex- } \\
\text { perimen- } \\
\text { tal error }\end{array}$ & $\begin{array}{c}\text { Unex- } \\
\text { plained } \\
\text { vari- } \\
\text { ations }\end{array}$ \\
\hline & $\begin{array}{c}\text { grams } \\
\text { per } \\
100 \text { cc. }\end{array}$ & $\underset{\mathrm{H}_{2} \mathrm{O}}{\mathrm{mm}}$ & $\underset{H_{2} \mathrm{O}}{m m}$ & $\begin{array}{c}\text { grams } \\
\text { per } \\
100 \mathrm{cc} .\end{array}$ & $\underset{H_{2} \mathrm{O}}{m m}$ & $\underset{\mathrm{H}_{2} \mathrm{O}}{\mathrm{mm}}$ & $\underset{\mathrm{H}_{2} \mathrm{O}}{\mathrm{mm}}$ & $\underset{\mathrm{H}_{2} \mathrm{O}}{m m}$ & $\begin{array}{l}m m . \\
\mathrm{H}_{2} \mathrm{O}\end{array}$ \\
\hline 6 & 4.68 & 47.6 & 49.0 & 6.74 & 321 & 330 & +9 & \pm 30 & \\
\hline 24 & 4.68 & 51.6 & 49.0 & 7.02 & 362 & 344 & -18 & \pm 30 & \\
\hline 18 & 4.69 & 50.5 & 49.1 & 7.92 & 400 & 389 & -11 & \pm 31 & \\
\hline 24 & 4.72 & 48.9 & 49.2 & 7.12 & 348 & 351 & +3 & \pm 31 & \\
\hline 34 & 4.72 & 50.5 & 49.2 & 6.87 & 347 & 338 & -9 & \pm 30 & \\
\hline 46 & 4.77 & 50.3 & 49.5 & 7.51 & 378 & 372 & -6 & \pm 31 & \\
\hline 11 & 4.77 & 50.0 & 49.5 & 7.13 & 357 & 353 & -4 & \pm 31 & \\
\hline 24 & 4.78 & 53.3 & 49.6 & 6.64 & 354 & 329 & -25 & \pm 30 & \\
\hline 13 & 4.78 & 50.4 & 49.6 & 6.91 & 348 & 343 & -5 & \pm 30 & \\
\hline 19 & 4.78 & 49.1 & 49.6 & 7.03 & 345 & 349 & +4 & \pm 31 & \\
\hline 53 & 4.79 & 51.9 & 49.7 & 7.14 & 371 & 355 & -16 & \pm 31 & \\
\hline 27 & 4.81 & 51.4 & 49.8 & 7.02 & 361 & 349 & -12 & \pm 31 & \\
\hline 12 & 4.84 & 51.4 & 50.0 & 7.50 & 385 & 375 & -10 & \pm 31 & \\
\hline 15 & 4.90 & 49.3 & 50.3 & 6.78 & 334 & 341 & +7 & \pm 30 & \\
\hline 14 & 4.91 & 48.5 & 50.4 & 7.58 & 368 & 382 & +14 & \pm 31 & \\
\hline 24 & 4.91 & 49.2 & 50.4 & 6.95 & 342 & 350 & +8 & \pm 31 & \\
\hline 24 & 4.92 & 49.1 & 50.4 & 7.07 & 348 & 357 & +9 & \pm 31 & \\
\hline 8 & 4.92 & 55.7 & 50.4 & 7.95 & 443 & 401 & -42 & \pm 32 & -10 \\
\hline 45 & 5.01 & 51.2 & 51.0 & 6.86 & 351 & 350 & -1 & \pm 31 & \\
\hline 12 & 5.02 & 49.0 & 51.0 & 7.70 & 377 & 393 & +16 & \pm 32 & \\
\hline 40 & 5.03 & 51.6 & 51.1 & 7.03 & 363 & 359 & -4 & \pm 31 & \\
\hline 1 & 5.06 & 52.3 & 51.3 & 6.86 & 359 & 352 & -7 & \pm 31 & \\
\hline 21 & 5.16 & 53.0 & 51.8 & 7.55 & 400 & 391 & -9 & \pm 32 & \\
\hline 29 & 5.18 & 53.6 & 52.0 & 8.26 & 443 & 429 & -14 & \pm 32 & \\
\hline 4 & 5.22 & 49.8 & 52.2 & 7.72 & 384 & 403 & +19 & \pm 32 & \\
\hline 34 & 5.32 & 54.0 & 52.8 & 7.96 & 430 & 420 & -10 & \pm 32 & \\
\hline 19 & 5.36 & 57.9 & 53.0 & 7.72 & 447 & 409 & -38 & \pm 32 & \\
\hline 13 & 5.44 & 52.2 & 53.5 & 8.07 & 421 & 432 & +11 & \pm 33 & \\
\hline 3 & 5.45 & 55.2 & 53.6 & 7.92 & 437 & 424 & -13 & \pm 32 & \\
\hline 53 & 5.48 & 54.2 & 53.7 & 7.82 & 424 & 420 & -4 & \pm 32 & \\
\hline 17 & 5.49 & 54.6 & 53.8 & 8.54 & 467 & 459 & -8 & \pm 33 & \\
\hline 24 & 5.55 & 52.1 & 54.1 & 8.11 & 423 & 439 & +16 & \pm 33 & \\
\hline 19 & 5.60 & 54.8 & 54.4 & 8.30 & 455 & 452 & -3 & \pm 33 & \\
\hline 21 & 5.93 & 56.2 & 56.4 & 8.66 & 487 & 488 & +1 & \pm 34 & \\
\hline 13 & 5.94 & 49.6 & 56.4 & 8.70 & 432 & 491 & +59 & \pm 34 & +25 \\
\hline 53 & 6.08 & 57.4 & 57.3 & 9.05 & 519 & 518 & -1 & \pm 34 & \\
\hline 15 & 6.14 & 56.9 & 57.6 & 8.68 & 494 & 500 & +6 & \pm 34 & \\
\hline 34 & 6.62 & 59.2 & 60.5 & 9.64 & 571 & 583 & +12 & \pm 36 & \\
\hline
\end{tabular}

seen to be quite definitely linear, this fact being indicated clearly by the general appearance of the surface produced by the tips of the wires, which lay, in general, in a plane which was parallel to the G-axis and inclined to the A-axis. These characteristics of the relationships are brought out in Figure 1, which shows the total lack of correlation between $\mathrm{S}$ and $\mathrm{G}$ and in Figure 2, which shows the high degree of correlation 
H. S. WELlS, J. B. YoUmans AND D. G. Miller, JR.

TABLE II

Tabulation of errors of calculation and experimental errors

\begin{tabular}{|c|c|c|c|c|}
\hline & Albumin & $\begin{array}{l}\text { Total } \\
\text { protein }\end{array}$ & $\begin{array}{l}\text { Specific } \\
\text { osmotic } \\
\text { pressure }\end{array}$ & $\begin{array}{c}\text { Total } \\
\text { osmotic } \\
\text { pressure }\end{array}$ \\
\hline 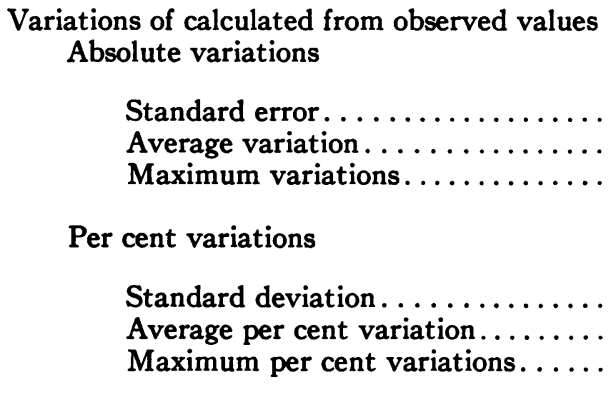 & & & $\begin{array}{l}m m . \mathrm{H}_{2} \mathrm{O} \\
\pm 2.23 \\
\pm 1.74 \\
+6.8 \\
-5.7 \\
\\
\text { per cent } \\
\pm 5.05 \\
\pm 3.87 \\
+18.7 \\
-13.1\end{array}$ & $\begin{array}{l}m m . \mathrm{H}_{2} \mathrm{O} \\
\pm 11.56 \\
+59.0 \\
-42.0 \\
\\
\text { per cent } \\
\pm 5.05 \\
\pm 3.89 \\
+18.4 \\
-13.2\end{array}$ \\
\hline 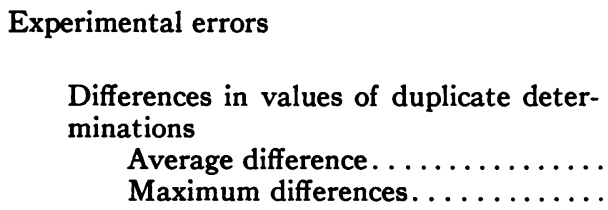 & $\begin{array}{c}\text { grams per } \\
100 \text { cc. } \\
\\
0.08 \\
0.39\end{array}$ & $\begin{array}{c}\text { grams per } \\
100 \text { cc. } \\
\\
0.09 \\
0.66\end{array}$ & & $\begin{array}{r}5.1 \\
19.0\end{array}$ \\
\hline
\end{tabular}

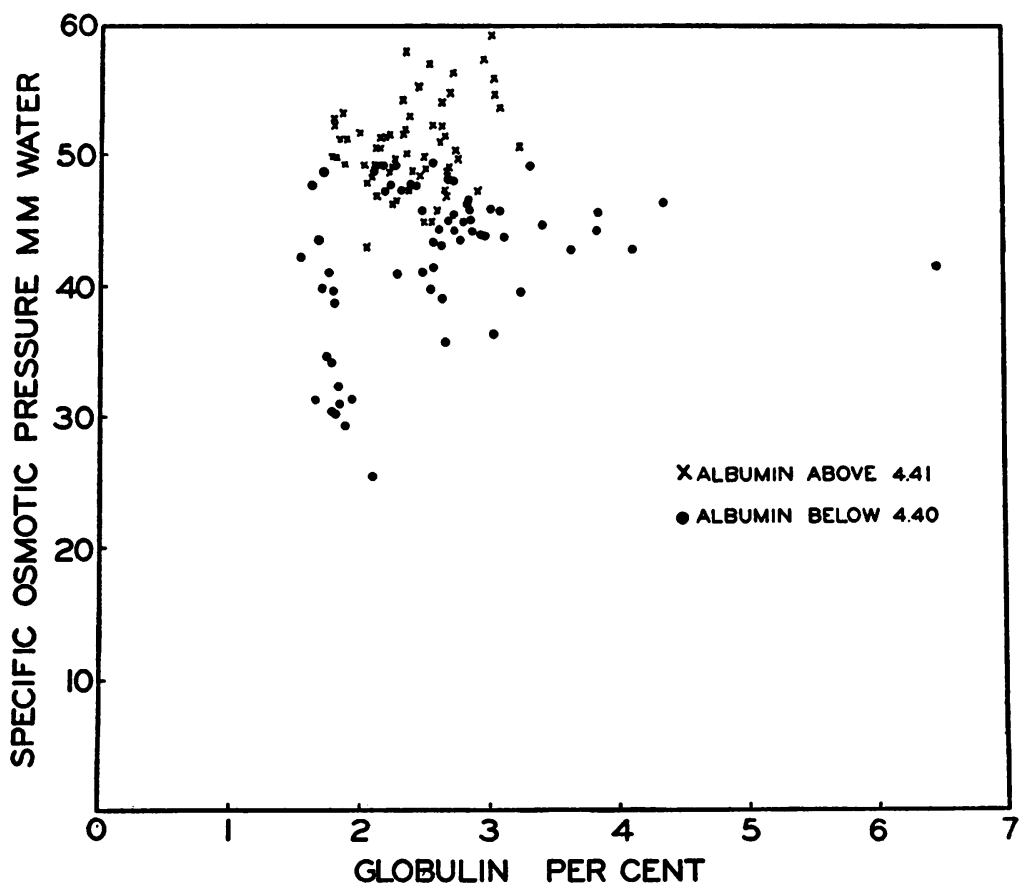

FIG. 1. Showing complete lack of correlation between specific osmotic pressure and globulin concentration. Higher values of $S$ correspond to high values of $A$, only; and lower values of $S$ correspond to lower values of $A$, only, regardless of values of $\mathrm{G}$. 


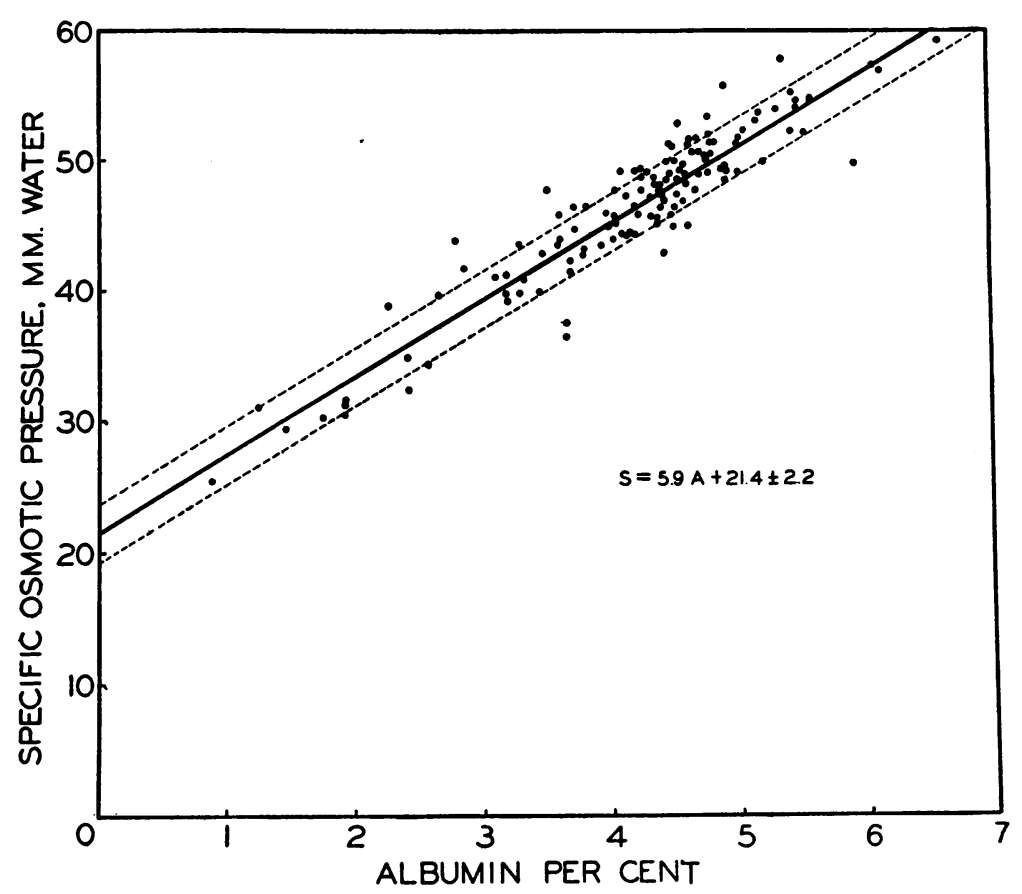

FIG. 2. Showing the linear relation of specific osmotic pressure to albumin concentration, as a straight line, fitted by the method of least squares. Correlation coefficient of $\mathrm{S}$ and $\mathrm{A}$ is $\mathbf{0 . 9 3}$. Standard error of calculation, indicated by dotted lines, is $\pm 2.2 \mathrm{~mm}$.

between S and A. The Pearson coefficient of correlation between $\mathrm{S}$ and A was found to be 0.93 , which indicates a high degree of relationship between the variables. The heavy line drawn through the points on the S-A graph is a straight line fitted to the data by the method of least squares. The equation of this line, $\mathrm{S}=5.9 \mathrm{~A}+21.4$ is corrected by means of the dotted lines on either side for the "standard error" of the calculated as compared to the observed values. The standard error being $\pm 2.2 \mathrm{~mm}$. of water, it may be prophesied on grounds of probability that, in any other similar series of measurements, the observed values of $\mathrm{S}$ will, in 68 per cent of the cases, fall within the range of values calculated from the formula $S=5.9 \mathrm{~A}+21.4 \pm 2.2$. Similarly, if the correction be doubled (twice the standard error being \pm 4.4 ) the range will include 95 per cent of observed values; while if the correction be trebled 99.7 per cent of cases should be included. Actually, in our series the percentage of cases included by the corrections corresponding respectively to the standard error, to twice the standard error, and to three times the standard error, are 72.6, 93, and 98.5. The frequency distribution of the errors is therefore quite according to the "normal distribution." The average 

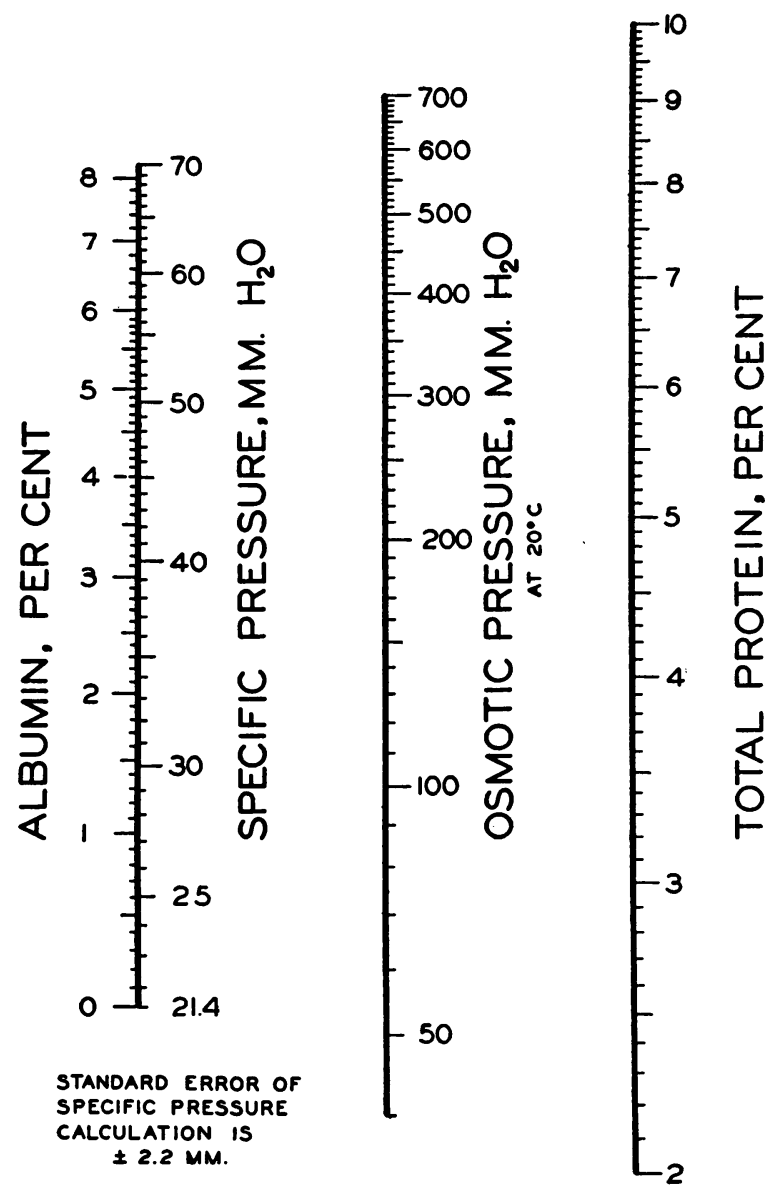

FIG. 3. Nomogram. A straight line drawn through the proper points on the albumin and total protein scales will intersect the middle scale at the value of the total osmotic pressure calculated from the formula, $\mathrm{P}=\mathrm{C}(21.4$ $+5.9 \mathrm{~A})$.

error of calculation of $\mathrm{S}$ was $\pm 1.74 \mathrm{~mm}$. and the maximum errors encountered were +6.8 and $-5.7 \mathrm{~mm}$.

The complete independence of the specific osmotic pressure from any effect of varying concentrations of globulin is exemplified by the findings on a sample of serum from the patient (Case Number 36) who suffered from Banti's disease. The albumin concentration was 2.87 per cent and the globulin concentration was 6.48 per cent, giving an A/G ratio of 0.44 . The observed specific osmotic pressure was $41.5 \mathrm{~mm}$. of water, while the value of $\mathrm{S}$ calculated from the albumin concentration is 38.3 . On the assumption that the globulin fraction of serum exerts, universally, a lower osmotic pressure, gram for gram, than the albumin fraction, one 
should expect the value of $S$ of a serum having such an unusually high globulin content to be lower than that calculated by our formula. The fact that it was actually higher, by nearly 8 per cent, indicates clearly the unreliability of the $A / G$ ratio as an index of the specific osmotic pressure, and confirms the idea that it is the albumin concentration which determines the specific osmotic properties of the serum.

The total osmotic pressure, $\mathrm{P}$, is calculated from the formula $P=C(5.9 \mathrm{~A}+21.4)$. The nomogram, reproduced in Figure 3, may be used to facilitate the calculations. The absolute error of the calculation of $\mathrm{P}$ is equal to the error of $\mathrm{S}$ multiplied by the concentration of total protein, C. The average error for our series was $\pm 11.6 \mathrm{~mm}$., the maximum errors being +59 and $-42 \mathrm{~mm}$. It is the percentage error of calculation of the total osmotic pressure, however, which will be most significant in practice. The percentage error will, in general, be the same for $\mathrm{S}$ as for $\mathrm{P}$, and for our series the average per cent error is slightly less than \pm 3.9 , the maximum errors being +18.7 and -13.2 per cent. The standard deviation of the per cent errors about their mean (which is -0.1 ) is \pm 5.05 , which signifies that 68 out of every 100 values of $S$ or $\mathrm{P}$, calculated by the given formulae, will correspond to the observed values within approximately \pm 5 per cent, and similarly 99.7 out of every 100 calculated values should check the observed values within \pm 15 per cent. Actually, errors lying within the ranges \pm 5 per cent and \pm 15 per cent occurred in 77 and 99 per cent of cases, respectively. The per cent errors of calculation may therefore be considered as being "normally" distributed.

\section{Sources of error}

The term "observed value," as used in the last paragraph, refers, in each case, to the average of the two values obtained from duplicate osmotic pressure determinations. However, in 4 instances, due to a scarcity of serum, only a single determination was run; but in only 1 of these cases was the variation between the observed and calculated values as great as $\mathbf{5}$ per cent. The greatest variation between the two values obtained from duplicate determinations was $19 \mathrm{~mm}$. The average variation was $5.1 \mathrm{~mm}$. and 95 per cent of the cases showed variations which were not greater than $12 \mathrm{~mm}$. In general there was no relation between the closeness of the check of the duplicate osmotic pressure determinations and the degree of variation of the observed mean pressure from the pressure calculated from the protein analyses.

The question naturally arises as to what extent the variations of the calculated from the observed pressures may be accounted for on the basis of experimental errors and to what extent they must be considered as due to unknown factors. We should like to be able to decide to what extent the osmotic pressure of colloids of serum is due to the protein concentrations as we have measured them and to what extent it is due 
to other factors that were not measured during these investigations. The average variation of calculated from observed values was $\pm 11.5 \mathrm{~mm}$. while the average variation of duplicate osmotic pressure determinations was only $5.1 \mathrm{~mm}$., or $\pm 2.55 \mathrm{~mm}$. when related to the means of the pairs of values. Unfortunately the variation of duplicate determinations is not always a measure of the error of a method. "Good checks," while reassuring, do not exclude the possibility that systematic errors may have affected both values to the same extent and in the same direction. Allowing for the possibility that systematic errors were present of a type which could affect our pairs of observations now in one direction, now in another, at random, we should be fairly safe in assuming, arbitrarily, that the "maximum expected error" will not be greater than $\pm 12 \mathrm{~mm}$., which is twice the variation from the mean of duplicate determinations in 95 per cent of our cases. We can neglect the possibility that systematic errors may operate in one direction for the whole series of cases for they could not be responsible for variations of observed values from values calculated by a formula based on the same series of observations.

The error of the chemical analysis of the albumin and total protein concentrations will contribute its share to the total error of the calculated value of the osmotic pressure. In 93 per cent of the cases the variations between duplicate determinations of these quantities were not greater than 0.2 gram per $100 \mathrm{cc}$. Assuming that the maximum expected error is \pm 0.2 gram per $100 \mathrm{cc}$. for albumin and also for total protein, the maximum, additive error of both analyses will be responsible for a possible error of from \pm 10 to $\pm 20 \mathrm{~mm}$. in the calculation of the osmotic pressure. By the method of differentials, where the pressure is calculated by the formula $\mathrm{P}=\mathrm{C}(21.4+5.9 \mathrm{~A})$, the total error is the total differential, $d P$. Now, $d P=21.4 d C+5.9 A d C+5.9 C d A$. Since $d A$ and $\mathrm{dC}$, the errors of the analyses, are both considered as \pm 0.2 , we have $\mathrm{dP}= \pm[1.2(\mathrm{~A}+\mathrm{C})+4.3]$. The maximum error of analysis was calculated in this way for each case, and the maximum experimental error found by adding the maximum error of the osmotic pressure determination, which is considered to be $\pm 12 \mathrm{~mm}$. The figures are given in the last column of Table I. Even with so great an allowance for errors of measurement, there were 6 instances in which the errors of calculation could not be accounted for. It is therefore necessary to assume that other factors, which were not measured, have a determining influence upon the osmotic pressure exerted by a given sample of serum. We may conclude that, whereas in a series of cases the errors due to the unknown factor or factors will not seriously affect the reliability of the calculation of the osmotic pressure from the albumin and total protein concentration, in any single instance the calculated value may possibly be in error by an amount which is much greater than the sum of the 
experimental errors of the methods employed. The unknown factor does not seem to be referable to individual ("personal") peculiarities of the blood, for in no instance did a large error occur more than once in the series of determinations carried out on blood samples from individual subjects. It may be assumed that the method of calculation will give reliable results when applied to a series of determinations on the same individual as well as when applied to single determinations on a series of several individuals. As a matter of fact, the greatest error so far encountered, 19 per cent, is not so great as to discourage the employment of the method, for most clinical purposes, for single determinations on single individuals. In this respect the method cannot be considered to be less accurate than the usual determination of the basal metabolic rate, for which an error of \pm 15 per cent is ordinarily allowed.

The significance of the relation between the specific osmotic pressure and the total protein and albumin concentrations. It has been pointed out by Marrack and Hewitt (7) that the "Donnan pressure" due to the excess of diffusible ions in a protein solution over that in the outside solution will be proportional to the square of the protein concentration and must be added to the osmotic pressure of the protein alone in calculating the total osmotic pressure of an ideal protein solution. Theoretically, therefore, $\mathrm{P}=\mathrm{aC}+\mathrm{bC}^{2}$, where $a$ is the constant of proportionality relating the pressure due to the protein alone to the concentration, and where $b$ is a constant relating to the Donnan pressure at constant $\mathrm{pH}$. The equation, of course, will be expected to hold for a series of blood sera only if they contain the same proportions of the two protein fractions, albumin and globulin: that is to say, when $A / G$ remains constant. But when $A / G$ is constant, $C$ is directly proportional to $A$, so that our equation for the total osmotic pressure, $\mathrm{P}=21.4 \mathrm{C}+5.9 \mathrm{AC}$, may be written $\mathrm{P}=21.4 \mathrm{C}+5.9 \mathrm{bC}^{2}$, where $b$ is the constant of proportionality between $\mathrm{C}$ and $\mathrm{A}$ for a constant value of $\mathrm{A} / \mathrm{G}$. This is the theoretical form of equation for the Donnan effect. Now $S=P / C$, so that the theoretical formula reduces to $S=a+b C$. For constant values of $A / G$ our equation may be reduced to the identical form, $\mathrm{S}=21.4+5.9 \mathrm{bC}$.

Interesting though these comparisons of our empirical equations with the theoretical Donnan equations may be, however, they do not completely explain the peculiar relations which we have found to exist. It is difficult to understand, on any theoretical basis which is not entirely speculative, why the specific pressure should be so completely independent of the globulin concentration and hence of the $A / G$ ratio. The relation would seem to imply that the specific pressure of globulin in any serum is the same as that of the albumin with which it is associated, and that it has a value which is directly determined by the concentration of the albumin. On the other hand, globulin does not appear to have any effect on the specific pressure of albumin. It should be emphasized that 
the term "specific pressure" refers not to the total osmotic pressure, but to the average pressure per gram per cent of total protein. The globulin content of a given serum appears to contribute gram for gram exactly as much to the total pressure as does the albumin. Consequently our data offer no justification for the assumption that albumin (in serum) has an effective molecular weight which is much less than that of globulin. The actual molecular weights of the two substances may, of course, be widely different: but if they are, the fact is not reflected in our data and we must assume that other factors enter in to mask the effects of a difference in molecular weight. Whatever the explanation of this peculiar situation may be, the existence of the relation indicates the need for an experimental study of the osmotic properties of both the separate and the mixed solutions of purified serum albumin and serum globulin.

The finding that the albumin concentration determines the specific osmotic pressure, not only of the albumin itself but also of the accompanying globulin (regardless of the concentration of the globulin) is of some significance in relation to the clinical correlation of edema with low serum albumin concentrations: for it becomes clear that a progressive lowering of the albumin content of a patient's serum entails a simultaneous lowering of the specific osmotic properties of the accompanying globulin fractions, even if the globulin concentration is not lowered.

The significance of the $A / G$ ratio as an index of the osmotic properties of serum depends, apparently, on the clinical fact that changes in this ratio are most often due to changes in the albumin fraction-the globulin changing relatively less, in most instances. However, in cases where the globulin undergoes marked variations from the normal value the $A / G$ ratio becomes totally unreliable as an index. In our series as a whole there is a fair degree of correlation between the specific pressure and the A/G ratio, but this must be attributed solely to the particular selection of cases. In individual cases the correlation was often very poor indeed.

The fact that the specific pressure increases with increasing total protein concentration (except when this increase is due to an increase in $\mathrm{G}$ alone) is in accord with the findings of many other investigators: for serum, $(8,9,10)$, for serum albumin (11), for other pure protein solutions $(12,13)$ and for all types of concentrated solutions of crystalloids so far studied, of which the classical example is sucrose (14). Consequently it would appear that the contention of Govaerts that the total protein concentration is without influence on the specific osmotic pressure is without justification except from his own data.

The apparent unreliability of the formulae of Govaerts and of von Farkas. In general the values obtained by Govaerts for the osmotic pressure of serum tend to be higher than those obtained by others. Further evidence that the values upon which Govaerts' formula is based are unreliable is given by the fact that Verney (8), employing cellophane membranes 
furnished by Govaerts, obtained values which were lower in relation to the protein concentrations than those of Govaerts, but of the same order of magnitude as those of most other workers.

We have used the formula of Govaerts, $\mathrm{P}=75.4 \mathrm{~A}+19.5 \mathrm{G}$, to calculate the osmotic pressures of our sera and find that these calculated values are, on the average, 18.4 per cent higher than the values which we observed, with a range of variation of -3 to +59 per cent. Since the formula of Govaerts fits his own data very well, we may conclude from the degree of variability found by the above-mentioned calculations that his observed pressures, mostly higher than ours, are not higher in any definite proportion but in a totally irregular manner. If our determinations are correct, as we believe them to be, it follows that Govaerts' formula cannot be relied upon to give calculated values which are even relatively accurate. The same criticism may be applied to the formula of von Farkas, $\mathrm{P}=68 \mathrm{~A}+25.1 \mathrm{G}$, for the application of this formula to our data provides values which are, on the average, 13.4 per cent higher than the values observed by us, the range of variation being -8 to +56 per cent.

\section{SUMMARY}

1. The osmotic pressure of colloids and the total protein, albumin and globulin concentrations of 128 samples of human serum were determined. The samples were obtained from 53 individuals.

2. Analysis of the data, which cover a relatively wide range of values, indicates that the relation between the total protein and albumin concentrations and the osmotic pressure is sufficiently regular and definite to allow the use of an empirical formula, derived from the data, for the calculation of the osmotic pressure. The formula is: $\mathrm{P}=\mathrm{C}(21.4+5.9 \mathrm{~A})$, where $\mathrm{P}$ is the osmotic pressure in millimeters of water, $\mathrm{C}$ is the total protein concentration and $\mathrm{A}$ is the albumin concentration, in grams per $100 \mathrm{cc}$. The standard error of calculation is \pm 5 per cent.

3. A nomogram has been constructed to facilitate calculations.

4. The specific osmotic pressure of serum appears to be a linear function of the albumin concentration. Variations in the globulin concentration over a wide range produce no effect on the specific pressure at constant values of $A$. Consequently the $A / G$ ratio is a poor index of the osmotic properties of serum. The specific pressure increases for increasing values of the total protein concentration, but only in so far as these increases are not due to increases in the globulin. The theoretical significance of these relations is discussed.

5. The formulae of Govaerts and of von Farkas, which have been used to calculate the osmotic pressure, appear to be totally unreliable. The reasons for this conclusion are discussed. 


\section{BIBLIOGRAPHY}

1. Govaerts, M. P., Bull. Acad. roy. de méd. de Belgique, 1927, xiii, 356. Influence de la teneur du sérum en albumines et en globulines sur la pression osmotique des protéines et sur la formation des oedèmes.

2. v. Farkas, G., Ztschr. f. d. ges. exper. Med., 1927, liii, 666. Studien über den kolloidosmotischen Druck des Serums.

3. Burk, N. F. and Greenberg, D. M., J. Biol. Chem., 1930, lxxxvii, 197. The physical chemistry of the proteins in non-aqueous and mixed solvents. I. The state of aggregation of certain proteins in urea-water solutions.

4. Wells, H. S., Am. J. Physiol., 1932, ci, 409. Some criteria of accuracy for the measurement of the osmotic pressure of colloids in biological fluids.

5. Wells, H. S., J. Tenn. Acad. Sci., 1933, viii, 102. A modified Krogh Osmometer for the determination of the osmotic pressure of colloids in biological fluids (with directions for its use).

6. Howe, P. E., J. Biol. Chem., 1921, xlix, 109. The determination of proteins in blood-a micro method.

7. Marrack, J. and Hewitt, L. F., Biochem. J., 1927, xxi, 1129. The effect of hydrogen ion concentration and protein concentration on the osmotic pressure of serum-proteins.

8. Verney, E. B., J. Physiol., 1926, lxi, 319. The osmotic pressure of the proteins of human serum and plasma.

9. Krogh, A. and Nakazawa, F., Biochem. Ztschr., 1927, clxxxviii, 241. Beiträge zur Messung des kolloid-osmotischen Druckes in biologischen Flüssigkeiten.

10. Fishberg, E. H., J. Biol. Chem., 1929, 1xxxi, 205. The relations of the serum proteins and lipids to the osmotic pressure.

11. Burk, N. F., J. Biol. Chem., (Proc.) 1931, xcii, xl. The molecular weight of serum albumin estimated by osmotic pressure measurements.

12. Kunitz, M., J. Gen. Physiol., 1926-27, x, 811. Hydration of gelatin in solution.

13. Adair, G. S., Proc. Roy. Soc. London, Series A, 1925, cix, 292. The osmotic pressure of hemoglobin in the absence of salts.

14. Porter, A. W., Tr. Faraday Soc., 1917, xiii, 123. The kinetic theory of osmotic pressure. 